\title{
Thermal imaging reveals massive heat accumulation in flowers across a broad spectrum of alpine taxa
}

\author{
Lars Dietrich • Christian Körner
}

Received: 13 December 2013/Accepted: 12 January 2014/Published online: 28 January 2014

(C) Swiss Botanical Society 2014

\begin{abstract}
By their small size, alpine plants escape free atmospheric convection and operate in a warm canopy climate depending on exposure and solar radiation. Inflorescences commonly protrude from that aerodynamically sheltered microenvironment and, thus, can be expected to experience a comparatively cooler climate. Using a highresolution thermal camera, we performed a mid-summer field survey in the Swiss Alps at $300 \mathrm{~m}$ above the climatic treeline to examine floral temperatures as related to solar radiation and flower diameter, height, brightness of flowering units and their area density across a sample of 43 alpine species. We show that flowers of alpine species are actually warmer (mostly $3 \mathrm{~K}$ ) rather than cooler than canopy foliage on bright days. The degree of heating largely depends on solar radiation, with flowering unit diameter and their area density as significant co-factors. Only in cushion plants, we found flowers to be slightly cooler than the compact leaf canopy. Abrupt shading of flowers revealed the dynamics of heat loss, with two-thirds of the extra heat lost in about 2-3 min. The study evidences that the size and shape of alpine flowers overcompensate the expected negative effects of greater wind exposure on experienced temperature as long as the sun is out. The thermal conditions for floral processes are, thus, not much different from lower elevation conditions during good weather. The remaining reproductive
\end{abstract}

Electronic supplementary material The online version of this article (doi:10.1007/s00035-014-0123-1) contains supplementary material, which is available to authorized users.

L. Dietrich $(\bowtie) \cdot$ C. Körner

Institute of Botany, University of Basel, Schönbeinstrasse 6, 4056 Basel, Switzerland

e-mail: lars.dietrich@unibas.ch constraints are related to the duration of such favourable periods and season length in general.

Keywords Floral traits · Temperature · Infrared · High elevation $\cdot$ Cold climate $\cdot$ Heat accumulation

\section{Introduction}

The success of alpine plants at elevations far above the climatic treeline largely rests upon their small stature, and thus aerodynamic decoupling from free atmospheric circulation leading to significantly warmer life conditions than those reported by weather stations at the same elevation (Körner 2003; Larcher 2012). Near the ground or just beneath the surface, where most species have their apical meristems, alpine plant communities may average at seasonal mean temperatures corresponding to mean air temperature measured at $0.5-1 \mathrm{~km}$ lower elevation (Scherrer and Körner 2010). The contrasts to air temperature are so large (4-8 Kelvin, K, across the growing season) that they exceed any extreme climate-warming scenario. Not surprisingly, the leaves of alpine plants have photosynthetic response optima to temperature not different from lowland grassland taxa (Körner and Diemer 1987). Yet, most of these microclimatic benefits of low stature materialize during the day, sunny hours in particular.

In strong contrast and despite the well-known size reduction in alpine species, individual flowers or whole compound inflorescences are commonly emerging from the calm aerodynamic boundary layer and they protrude into well-stirred air above the leaf canopy for reasons related to pollinator attraction or wind-mediated pollination. One would thus expect that flowers of alpine plant species operate at cooler temperatures, closer to air temperature and 
certainly cooler than the bulk of the leaf canopy, except perhaps for sessile flowers on cushion plants. But even in the latter, flowers are more exposed to wind than the compact leaf canopy.

At high elevation, the short-growing season adds to the thermal limitation of life and the annual reproductive cycle, particularly in late flowering taxa, is under tough time limitation. It is, in fact, surprising that late flowering taxa do exist. Since all metabolic processes depend on temperature (We have no reason to assume that reproductive units make an exception), the exposure of reproductive units to convective forcing above the leaf canopy seemingly represents a disadvantage in a cold climate. Although the critical steps of embryogenesis and seed maturation can proceed exceptionally fast (Wagner and Mitterhofer 1998; Steinacher and Wagner 2012) and many alpine species form their flowers (buds) in the previous season (inflorescence preformation; Körner 2003; Wagner et al. 2012), the challenge remains, how alpine flowers pass through the complete cycle of flower establishment, anthesis and all steps of seed maturation at positions that are a priori unfavourable for departing significantly from adverse ambient temperature conditions. This raises the question, whether inflorescences have evolved means to enhance temperature around the sexual organs during development (archespor activity, oogenesis, pollen tube growth, initial embryogenesis).

A number of researchers have addressed this question, but the small size and often delicate structure of alpine flowers makes it rather challenging to measure temperatures in the critical part of inflorescences. Sklenár (1999), e.g. showed that downward pointing inflorescences of some Asteraceae in the Andes benefit thermally from the reflected radiation of the substratum (especially snow) while minimizing the risk of getting moistened by rainwater or melting snow. In Saussurea medusa, a Himalayan Asteraceae, overlapping bracts around the inflorescence help to rise the temperature directly under the bract-coat (Tsukaya et al. 2002). Yet, the pubescence of the bracts is likely not an adaptation to the cold environment but may prevent floral wetting in this monsoonal environment (Yang et al. 2008).

An issue related to tissue 'air conditioning' in inflorescences is flower heliotropism-the active positioning of flowers to the sun, so that a maximum of solar heat can be trapped. The number of alpine species that perform solar tracking is rather small, however, and is restricted to a few upward facing unitarian flowers such as in Ranunculus, Dryas or Papaver species (Kevan 1975; Stanton and Galen 1993; Totland 1996). Composite inflorescences such as in Asteraceae, Dipsacaceae, some Scrophulariaceae and Orchidaceae, commonly do not perform solar tracking, and neither do most bell-shaped flowers such as in Campanulaceae, Gentianaceae and Ericaceae. However, many species perform diurnal opening and closing of inflorescences or flowers, presumably to prevent wetting or excess radiative cooling in clear nights (van Doorn and van Meeteren 2003). It had been shown that alpine flowers that track the position of the sun, benefit from warmer temperatures in the centre of the flower (Stanton and Galen 1989; Totland 1996; Luzar and Gottsberger 2001), and also flowers that do not perform heliotropism experience a similar effect (Zhang et al. 2010).

The technological advance in the field of thermal imaging now offers unprecedented possibilities to screen in great detail the thermal conditions in alpine inflorescences. In this study, we surveyed a broad spectrum of alpine species at ca. $300 \mathrm{~m}$ above the climatic treeline in mid-summer for their ability to accumulate heat. Given the obvious drivers are solar energy and the size of the flowering unit, we paid particular attention to these factors. Past works used ambient air temperature as a reference to define flower warming. Since the leaf canopy warms as well (see above) it remains unresolved how much flower temperatures depart from the concurrent bulk foliage temperature. The thermal imaging technique now permits capturing both, an integrated mean of foliage temperature in the leaf canopy beneath inflorescences, as well as the temperature of the flowering unit in one image.

We expected (1) flowers to be warmer than air temperature, but significantly cooler than the leaf canopy, that (2) flowering units will be warmer the more intense solar radiation and the larger their diameter, and (3) that flower brightness plays no additional role, but we acknowledge the trade off in terms of pollinator visibility (the brighter the better) and floral warming (the darker the warmer). Should plants prioritize visibility we would expect compensatory evolution so that bright flowers form denser inflorescences (size compensating aerodynamically and via heat capacity for the disadvantage of brightness in terms of reflection). Since the principles of the physics of solar heating do not change with time and space, a mid-summer survey across a broad sample of taxa should provide conclusive answers to these questions.

\section{Materials and methods}

\section{Study site and studied species}

Study site chosen for measurements was an alpine grassland on two south-facing slopes $\left(46^{\circ} 34^{\prime} \mathrm{N}, 8^{\circ} 25^{\prime} \mathrm{E}\right)$ situated in southern Switzerland close to the Furka Pass at 2,430 m a.s.l. with an annual precipitation amount of about 2,000 $\mathrm{mm}$. Annual mean temperature at the Furka Pass is $0.3^{\circ} \mathrm{C}$, while the mean daily temperature during the study period (end of July) was about $10{ }^{\circ} \mathrm{C}$ with average minimum and maximum temperatures of 3.6 and $15.9{ }^{\circ} \mathrm{C}$. Both slopes were rich in 
microtopography but constant in macroexposure. Vegetation was very diverse with a high proportion of Asteraceae, but dominated by graminoids such as Festuca violacea, Poa alpina, Juncus jaquinii or Carex curvula. All species chosen for measurements (43 species in total, Electronic supplementary material 1) are well known to have an alpine distribution. For this broad survey, species were chosen by availability, for the more specific individual tests (6 species), we selected species for image quality, orientation and different shape and size of their flowering units. In case of Asteraceae and the species Carex atrata, Carex nigra, Phleum alpinum and Nigritella rhellicani, the whole compound flower/inflorescence was considered as one functional flowering unit while for the other species only one single of all flowers was chosen. To avoid confusion using the words flower, inflorescence or compound flower in parallel, we will use the term flowering unit as a substitute in the following. For information about the regarded flowering unit of the species in particular see Electronic supplementary material 1.

\section{Meteorological data}

As a reference, temperature of the air was measured $1 \mathrm{~m}$ above ground near the respective flowering unit manually by a sling psychrometer (Relative Humidity Meter ${ }^{\odot}$; Bacharach Inc., New Kensington, USA). Weather conditions during the campaign were slightly windy but fairly constant, mostly sunny and dry but periodically cloudy, which permitted taking images at different radiation intensities. Solar radiation intensity was measured manually by a photon flux sensor (LI-250A ${ }^{\circledR}$; LI-COR Biosciences, Lincoln, USA) held horizontally directly over the flowering unit immediately after taking the IR image. We also used photon flux density data from an automatic weather station at 2,440 m a.s.l. at the Furka Pass (ALPFOR station).

\section{IR camera measurements and data analysis}

The temperature of the flowering units and foliage was measured by images of an infrared camera (VarioCAM ${ }^{\circledR}$; Infra Tec GmbH, Dresden, Germany) and evaluated by software (IRBIS professional, InfraTec GmbH, Dresden, Germany). The IR camera records long-wave infrared radiation in a spectral range from 7.5 to $14 \mu \mathrm{m}$ at a resolution of 76.800 image points $(320 \times 240$ pixels $)$ and converts the radiation into temperature with a resolution of $\pm 0.1 \mathrm{~K}$ among pixels. According to previous experiments, the emissivity of vegetation was assumed to be close to 1 ( $>0.98$ according to Rubio et al. 1997; cf. Scherrer and Körner 2010). Temperatures measured manually with fine-wire thermocouples in a subsample of species at the same site yielded similar temperature contrasts between the centre of flowering units and air or foliage temperature (data not shown). Whenever possible, IR images were taken at a right angle to the plane of the flowering unit, so that the camera could view the centre bottom of a flowering unit. All infrared (IR) images were taken from flowering units from the side pointing toward the sun, irrespective of their orientation to the vertical. We took images only when the weather conditions were stable for at least the last $3 \mathrm{~min}$, and replicated IR images in several (3-12) individuals spread over several dry and sunny days around the noon hours (for number of visits see Electronic supplementary material 1). Floral temperatures of the inner region of the flowering unit containing the female and male reproductive organs were considered as 'flower temperature' and, thus, excluded the temperature of peripheral parts of petals, ray florets and bracts (Asteraceae) protruding beyond the reproductive organs. For the mean temperature of the foliage, a straight line was drawn by software through an area of the respective photo in which the vegetation cover was situated. The mean temperature of the pixels on this line was determined (cf. Fig. 1). For floral temperatures, an adequate polygon was placed into the critical part of the flowering unit and the mean temperature of that area was calculated by software. For the shading experiments, IR images of three species (Aster alpinus, N. rhellicani and J. jaquinii) were taken initially under full solar radiation, followed by abrupt shading with a cardboard. From then on, every $10 \mathrm{~s}$ an IR image of the respective flowering unit was taken and radiation intensity was measured until no further cooling was noticed on the camera display.

Flowering unit diameter was measured with a ruler for the critical inner parts of the flowering unit, height was determined from the soil to the starting point of the flowering unit. For gathering data about flowering unit brightness, flowering units were divided into three groups of brightness ( 1 for bright -3 for dark). For the same species studied in greater detail (see below), we also measured flowering unit area density by expressing the projected (top view) area of the flowering unit per unit of fresh and dry weight. In Asteraceae, we disregarded sterile ray petals. For Juncus, we used the side view area because of the flattened shape of the ear. Differences between floral temperatures and foliage temperatures as well as differences between floral temperatures and the temperature of the ambient air $(1 \mathrm{~m})$ were calculated. The significance of the relationship between solar radiation and temperature differences between flowering units and the ambient air or the leaf layer, respectively, was tested by simple linear regression analysis. Dependency between all factors including solar radiation, height of the flowering unit, flowering unit diameter, brightness and area density (the latter only for the six closer considered species) was tested by simple linear regression and two-way ANOVA. Statistical analyses were done using $R$ (R Foundation for Statistical Computing. Vienna. Austria 2013) assuming a $5 \%$ level for significance. 

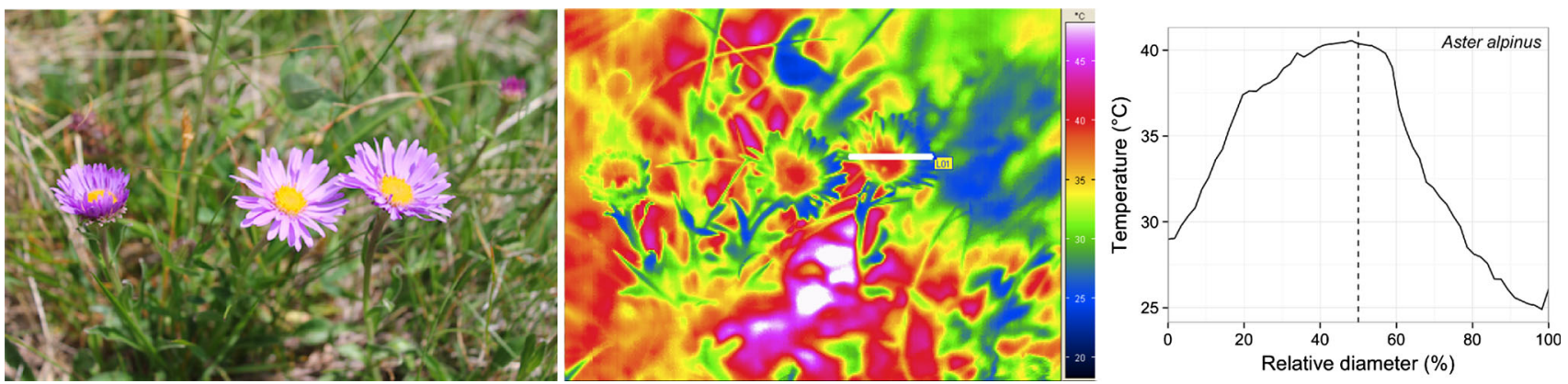

Fig. 1 Real and IR image of Aster alpinus with temperature profile through one compound flower. The T-profile graph matches the white line in the IR image from left to right

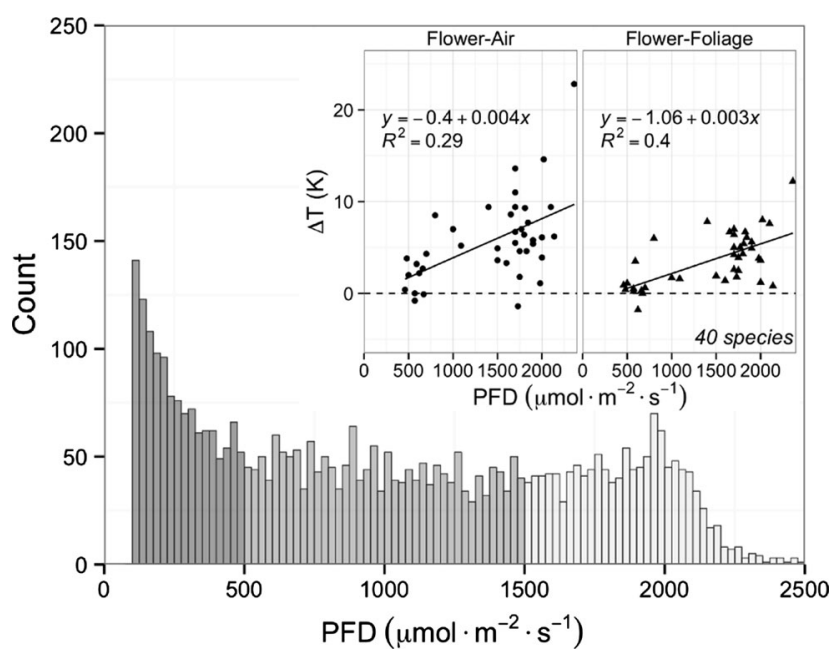

Fig. 2 Frequency distribution of photon flux density (PFD) for July 2012 and 2013 at Furka Pass, 2,440 m a.s.l. (10-min intervals, daylight hours $>100 \mu \mathrm{mol} \mathrm{m} \mathrm{m}^{-2} \mathrm{~s}^{-1}$ ). We show the most commonly used PFD, although it is the energy balance $\left(\mathrm{W} \mathrm{m}^{-2}\right)$ which matters for flower temperature. PFD can be converted to global radiation $\left(\mathrm{W} \mathrm{m}^{-2}\right.$ ) by multiplying PFD by 0.22 . Inset diagram: The influence of PFD on the difference between flowering unit temperature and either air or foliage temperature for 40 different alpine species (each point one species; Table of Electronic supplementary material 1 without cushion plants). Both linear regressions are significant at $p<0.001$

\section{Results}

\section{Impact of solar radiation}

Across all 40 sampled species (Fig. 2), we found a positive correlation between solar radiation (here expressed as photon flux density, PFD) and temperature difference (flowerair and flower-foliage). Temperature differences between flowering units and foliage ranged from $-1.8 \mathrm{~K}$ at low PFD in the small compound flower of Homogyne alpina (at $620 \mu \mathrm{mol} \mathrm{m} \mathrm{m}^{-2} \mathrm{~s}^{-1}$ ) to $12.2 \mathrm{~K}$ at high PFD in A. alpinus (at $\left.2,363 \mu \mathrm{mol} \mathrm{m} \mathrm{m}^{-2}\right)$. Daytime PFD $\left(>100 \mu \mathrm{mol} \mathrm{m}{ }^{-2} \mathrm{~s}^{-1}\right)$ of July 2012 and 2013 shows that roughly one-third of the daylight hours falls in the $>1,500 \mu \mathrm{mol} \mathrm{m} \mathrm{m}^{-2} \mathrm{~s}^{-1}$ category during which we obtained our high radiation temperature relation. One-third of the daylight hours $\left(<500 \mu \mathrm{mol} \mathrm{m}{ }^{-2} \mathrm{~s}^{-1}\right)$ does not permit flowering unit temperature to significantly depart from air temperature. Values over $2,000 \mu \mathrm{mol} \mathrm{m}{ }^{-2} \mathrm{~s}^{-1}$ reflect conditions during which direct solar radiation adds up with diffusive re-radiation from scattered thin clouds.

The linear regression analysis for the six species examined more intensively (Fig. 3) shows a strong positive correlation between PFD and temperature differences with a stronger influence of radiation (steeper slope) for the flowerair temperature differences $(p<0.001$ for 5 species, $p<0.05$ for J. jaquinii). A. alpinus was the species heating up most under solar radiation with peak temperature differences of $23.6 \mathrm{~K}$ (flower-air) and $16.9 \mathrm{~K}$ (flower-foliage) at highest PFD. The highest absolute temperature was $39.1{ }^{\circ} \mathrm{C}$ (also A. alpinus). J. jaquinii and $N$. rhellicani showed the lowest heating of the six species (maximum differences flower-air: 14.2, $14.3 \mathrm{~K}$; flower-foliage: 8.8, $12.1 \mathrm{~K})$. Flowers of cushion plants [Arenaria ciliata, Loiseleuria procumbens, Silene acaulis (Fig. 4)] turned out to be warmer than the air, but cooler than foliage. The shading experiments show that two-thirds of the temperature difference between flowers and air is lost in the first 2-3 min after shading. The temperature of the flowers of all three tested species decreases quite fast and seems to approach the air temperature asymptotically as expected by the physics of heat dissipation (Electronic supplementary material 2).

\section{Effects of other variables}

No significant correlation was found between temperature differences and the height of the respective flowering unit or its brightness. Within a PFD range $>1,000 \mu \mathrm{mol} \mathrm{m}{ }^{-2} \mathrm{~s}^{-1}$, a correlation between flowering unit diameter and temperature difference (flower-foliage) is obtained (Fig. 5, $p<0.01$ ) by linear regression. The two-way ANOVA revealed a significant effect of diameter across the whole 

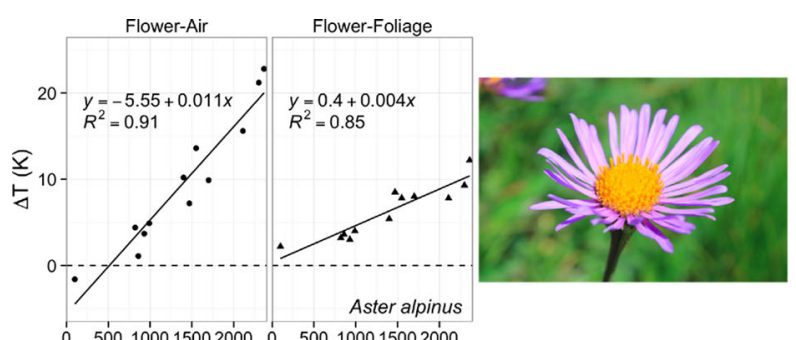

o $500100015002000 \quad 0^{\prime} \quad 500100015002000$ PFD $\left(u \mathrm{~mol} \cdot \mathrm{m}^{-2} \cdot \mathrm{s}^{-1}\right)$
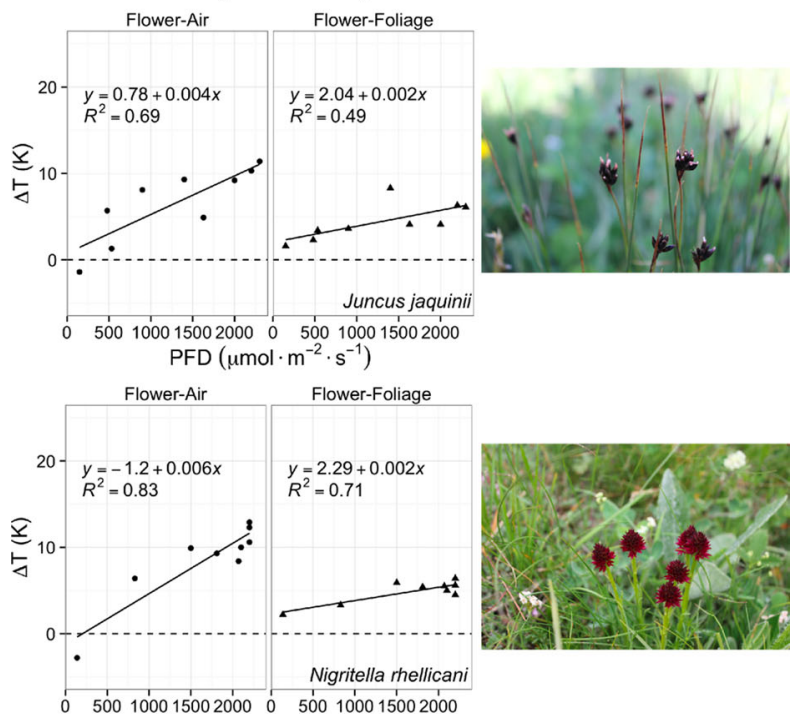

o $500100015002000 \quad 0^{\prime} 500100015002000$ PFD $\left(\mu \mathrm{mol} \cdot \mathrm{m}^{-2} \cdot \mathrm{s}^{-1}\right)$
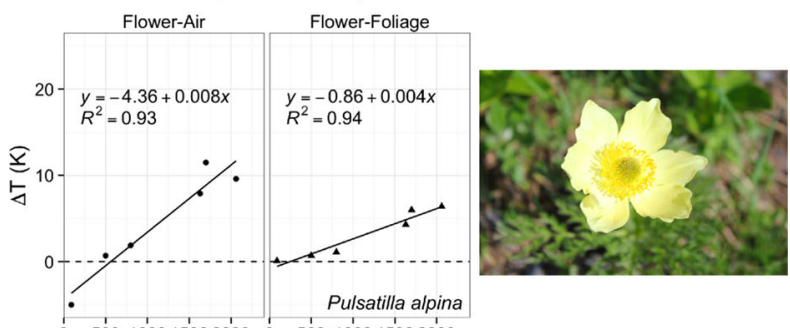

$0 \quad 500100015002000 \quad 0 \quad 500100015002000$ PFD $\left(\mu \mathrm{mol} \cdot \mathrm{m}^{-2} \cdot \mathrm{s}^{-1}\right)$
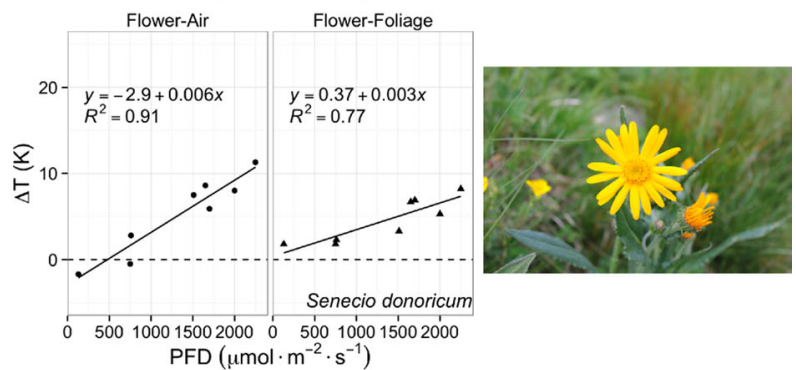
PFD $\left(\mu \mathrm{mol} \cdot \mathrm{m}^{-2} \cdot \mathrm{s}^{-1}\right)$
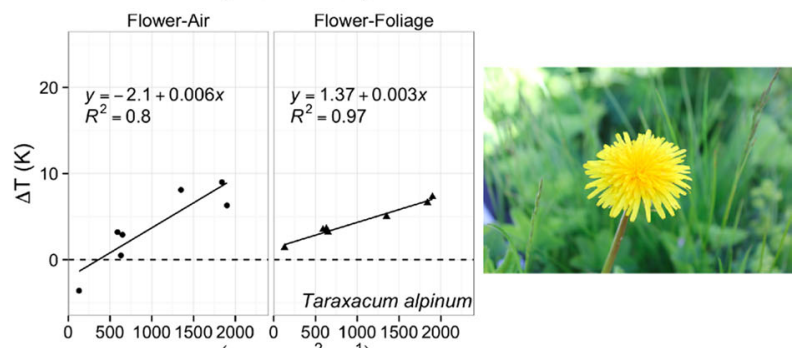

4 Fig. 3 Linear regressions for the correlation between temperature difference (flower-air and flower-foliage) and photon flux density (PFD) for six closer considered species. Each regression except for $J$. jaquinii (flower-foliage) turned out to be significant at $p<0.001$. For $J$. jaquinii, the regression for $\Delta T$ flower-foliage was significant at $p<0.05$. Each value represents one flowering unit on one individual of the considered species
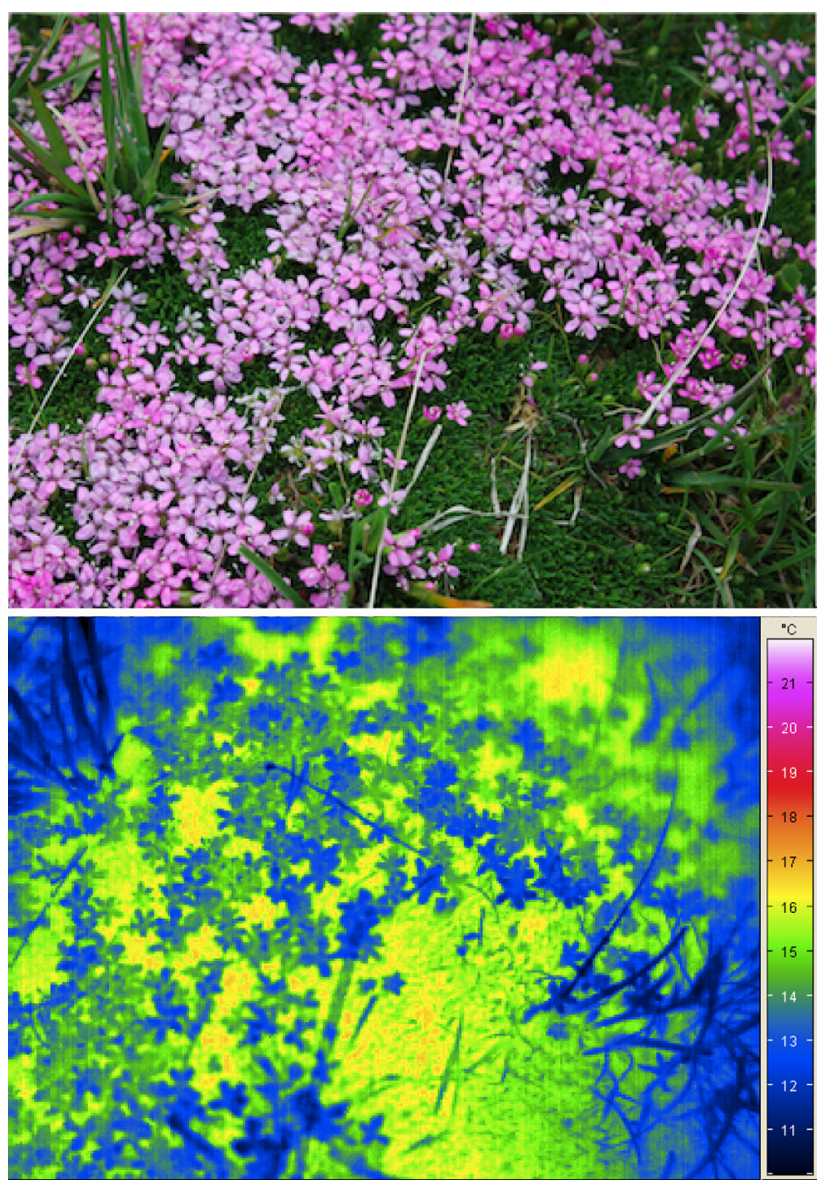

Fig. 4 Real and IR image of Silene acaulis, a cushion plant of the Alpine, at PFD of $480 \mu \mathrm{mol} \mathrm{m} \mathrm{m}^{-2}$

PFD range. Flowering unit fresh and dry area density of all six closer considered species (Table 1 ) has a positive significant effect ( $p<0.001$ for both, fresh and dry). Flowering unit water content was the same for all six species $(\sim 80 \%)$.

Temperature distribution within flowering units

The point of highest floral temperature for many species (especially Asteraceae) is situated nearly in the middle of the flowering unit (Fig. 6) and is decreasing towards the margin. Right at the edge of the flowering unit background temperature comes into view, hence temperatures rise again (tails of some profiles). Temperatures inside the flowering unit 


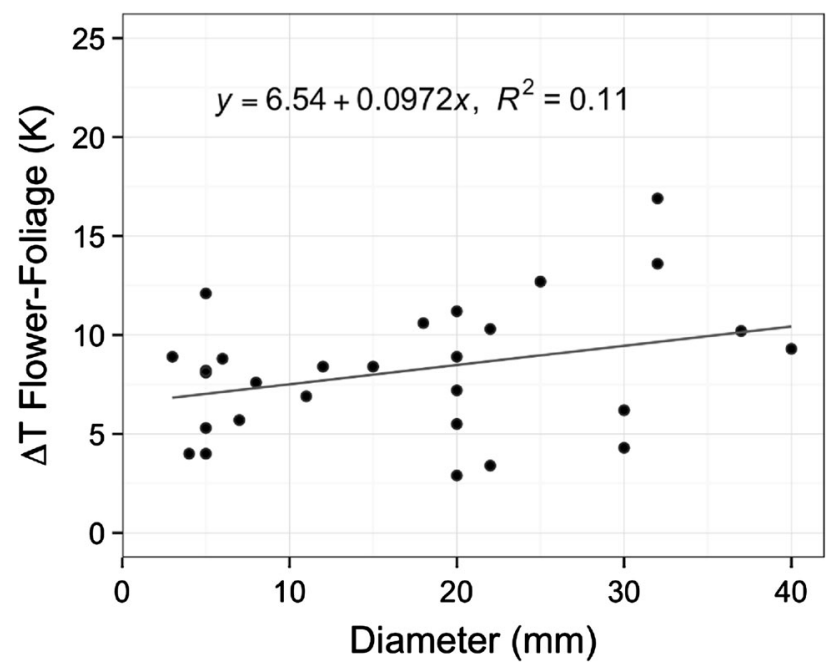

Fig. 5 Linear regression analysis for the dependence of $\Delta T$ flowerfoliage on flowering unit diameter in a PFD range between 1,000 and $2,400 \mu \mathrm{mol} \mathrm{m} \mathrm{m}^{-2} \mathrm{~s}^{-1}(p<0.01)$. Diameter was measured with a ruler, ignoring petals, tepals or ray florets exceeding the centre of the flowering unit

Table 1 Flowering unit area density (fresh and dry weight per unit area) $\pm \operatorname{SE}(n=5)$ of the six species examined in more detail

\begin{tabular}{llc}
\hline Species & $\begin{array}{l}\text { Flowering unit area density } \\
\text { fresh }\left(\mathrm{mg} / \mathrm{mm}^{2}\right)\end{array}$ & $\begin{array}{l}\text { Flowering unit area } \\
\text { density dry }\left(\mathrm{mg} / \mathrm{mm}^{2}\right)\end{array}$ \\
\hline $\begin{array}{l}\text { Aster alpinus } \\
\text { Juncus }\end{array}$ & $4.41 \pm 0.29$ & $1.2 \pm 0.06$ \\
$\quad$ jaquinii & $3.79 \pm 0.22$ & $0.11 \pm 0.01$ \\
$\begin{array}{c}\text { Nigritella } \\
\text { rhellicani }\end{array}$ & $1.99 \pm 0.26$ & $0.33 \pm 0.04$ \\
$\begin{array}{c}\text { Pulsatilla } \\
\text { alpina }\end{array}$ & $7.45 \pm 0.7$ & $1.45 \pm 0.08$ \\
$\begin{array}{c}\text { Senecio } \\
\text { donoricum }\end{array}$ & $6.38 \pm 0.22$ & $1.32 \pm 0.06$ \\
$\begin{array}{c}\text { Taraxacum } \\
\text { alpinum }\end{array}$ & $8.43 \pm 1.06$ & $1.4 \pm 0.21$ \\
\hline
\end{tabular}

Flowering unit area and weight were determined without ray florets or petals exceeding the centre of the flowering unit containing the reproductive organs

were maintained across the inner parts at a relatively high level before decreasing towards the edge.

\section{Discussion}

We show for a broad spectrum of alpine taxa that flowering units are significantly warmer than foliage or air when the sun is out. Peak flowering unit temperatures can rise to a maximum of $39.1{ }^{\circ} \mathrm{C}$ (A. alpinus) at high solar radiation and are mostly around $3 \mathrm{~K}$ above foliage temperature $(6 \mathrm{~K}$ above air temperature) under such conditions. Luzar and Gottsberger (2001) found at similar elevation and sunny weather in the Grossglockner region, Austria, a warming of ca. $5 \mathrm{~K}$ in Ranunculus montanus, which matches with our own value for Ranunculus aconitifolius (at $1,830 \mu \mathrm{mol} \mathrm{m}{ }^{-2} \mathrm{~s}^{-1}$ ), which has a rather similar-sized flower.

Solar radiation is the main driver of floral heating in such an alpine environment. Flowering units in spring ephemerals have also been demonstrated to warm largely in response to solar radiation up to $22-26{ }^{\circ} \mathrm{C}$ (Rejskova et al. 2010). However, the finding of Rejskova et al. (2010) that compound flowers of Bellis perennis get cooler at very high solar radiation than at minor radiation values, what they explain by floral transpiration, does not match our observations. Transpirational cooling of heliotropic flowers was also found by Galen (2006) in an alpine population of Ranunculus adoneus and could be perceived to avoid floral overheating while significantly rising water loss.

From a physical point of view, it is not surprising that flowering units become warmer than the ambient air. What is surprising is the fact that despite their exposure, flowering units warm more than foliage under high radiation. Thermally, flowering units must be somewhat better decoupled from to the surrounding air than canopy foliage. Especially Asteraceae species seem to be very successful in floral warming. The comparatively large compound flowers combined with dense structures and an often darker centre could be an explanation. In addition to the thermal benefits during the maturation of sexual organs in the central part of the flowering units, pollen germination and pollen tube growth may also profit. For example, the rate of pollen tube growth is distinctly faster at higher temperatures (Galen and Stanton 2003; Song et al. 2012; Steinacher and Wagner 2012). Also final seed weight shows a positive correlation with gynoecium temperature (Kjellberg et al. 1982; Stanton and Galen 1989). Higher floral temperatures in an otherwise cool environment can, thus, be critical or at least an advantage for the successful reproduction of high-mountain plants.

In our alpine test area, PFD seems to be quite supportive for floral heating during the flowering period. With this result, we can assume that at least in a third of the midsummer daylight hours, flowering units exhibit temperatures which correspond to air temperatures at ca. 1,000 m lower elevation.

In terms of flowering unit warming, A. alpinus is the most profiting of the six species considered more closely, which is surprising when compared to the two other Asteraceae species, Senecio donoricum and Taraxacum alpinum, which have an even higher flowering unit size and density (area density, fresh). Maybe the slightly upward sloped ray florets of A. alpinus protect the darker disc florets from wind, which can thus maintain higher temperatures for a longer period. In addition, the comparatively shorter stem length of A. alpinus 

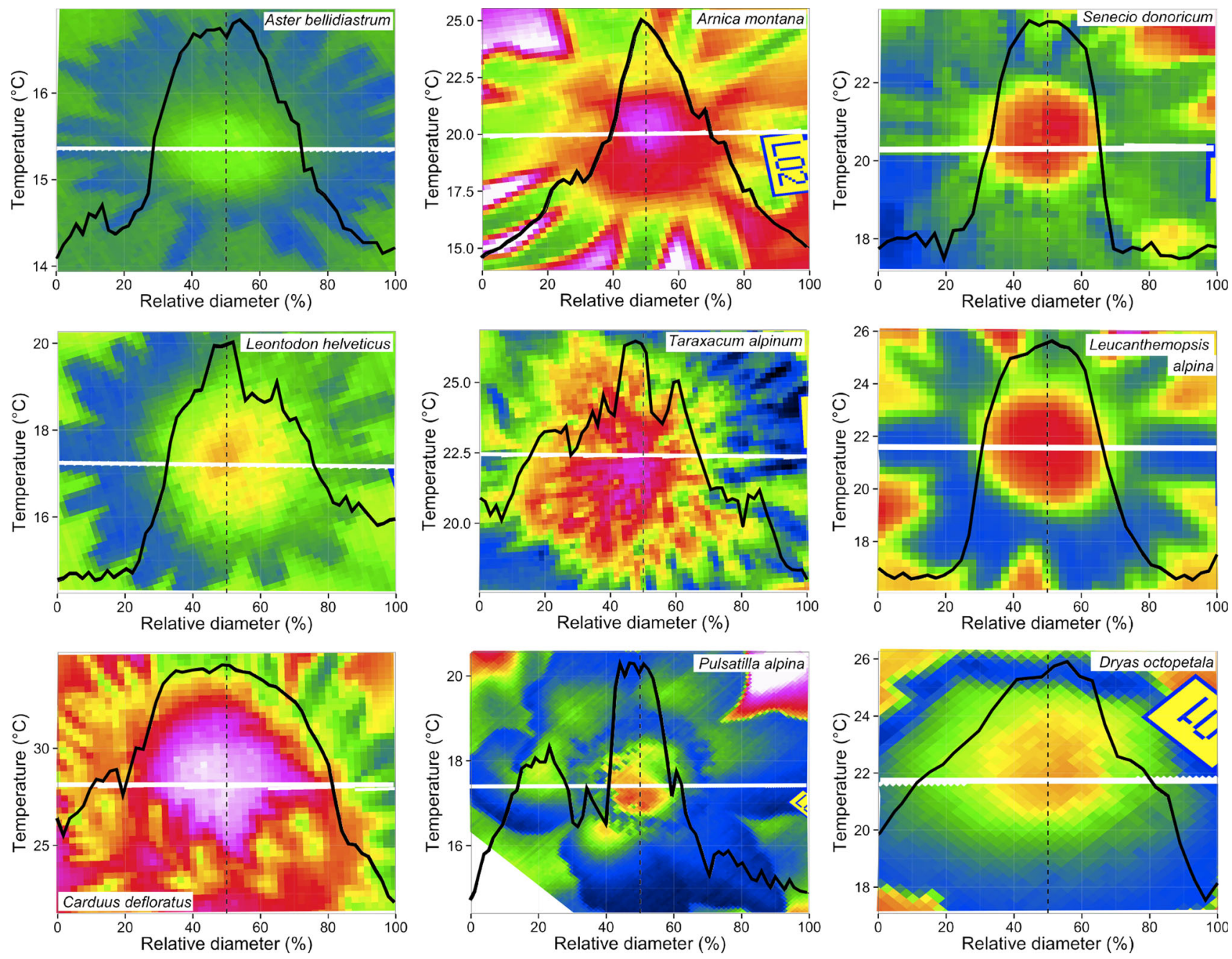

Fig. 6 Temperature profiles across flowering units of six alpine species. The quality of the pictures is partially pixelated due to zooming them out of existing IR images. The T-profile matches the white line in each picture from left to right. Please note that scaling of

may enhance decoupling from the colder free atmosphere. Pulsatilla alpina is also quite successful. This species may take advantage from some solar tracking and the sun-oriented, parabolic shape, with the deep parts of the flower well protected from wind. Similarly, floral warming in Dryas species has been associated with such traits (e.g. Kevan 1975; Kudo 1995). The weaker but still substantial thermal responses of J. jaquinii and $N$. rhellicani to solar radiation are not surprising considering the lower specific area density of their flowering units, smaller diameter and less or no orientation towards the sun. On the other hand, these species are the only two with dark (almost black) flowers. The up to 8.8-12.1 $\mathrm{K}$ warming in these species may be related to reduced reflectance in the visible spectrum. However, due to their smaller mass, heat dissipation will also be progressing faster after shading. We saw no risk of floral overheating in any species. The heat resistance is well above the highest the $y$-axis (Temperature) is not consistent for the sake of a more contrasted photo and neither is heat dependence of colour. Thus, the quantitative power of this graphic is reduced

temperatures we observed (Gauslaa 1984; Larcher et al. 2010; Körner 2003).

Cushion plants deviate from the overall patterns by showing cooler temperatures in flowers than in foliage. In this case, foliage is packed so densely in a kind of 'heat-trap' fashion (Körner 2003) so that flowers on top of such cushions are even cooler due to their better connection to the atmosphere and, presumably, their brightness. But, admittedly, it was quite difficult to capture critical parts of cushion plant flowers in IR images because of their small and often bell-shaped form. Ovaries that lie very close to the foliage such as in S. acaulis or L. procumbens can profit from the heat trapped inside the cushion (Philipp et al. 1990), but at the same time may be at risk of being damaged by an overheated cushion foliage at high solar radiation.

The cooling by shade experiments showed that thermal benefits of alpine flowering units are quickly lost once solar 
radiation is shielded off. Rejskova et al. (2010) also found thermal benefits of flowering units in Anemone nemorosa and $B$. perennis to vanish within $90-120 \mathrm{~s}$ after shading by clouds at low elevation. Surface warming of flowering units under sudden direct solar radiation may in fact proceed faster than the dissipation of heat that had accumulated in the body of the flowering unit. Therefore, the mass of flowering units (and also the area density of the flowering unit) can be regarded as a second important factor after solar radiation, contributing to thermal benefits of alpine flowers. Species with denser or heavier flowering units (containing more water) benefit more from radiation in terms of heat storage during strongly variable solar radiation. The diameter of the flowering unit also contributes significantly to heat accumulation, reflecting the well-known dependency of aerodynamic boundary layer resistance on the dimension of the receptive structure (Jones 2014). Thus, besides pollinator attraction, heat accumulation may be a second selective advantage of comparatively large flowering units in alpine plants. The diameter of flowering units in alpine taxa has been found to be similar to that in lowland taxa despite their overall height reduction (Fabbro and Körner 2004; Zhu et al. 2009). The fact that flowering unit height had no significant effect is unexpected, because wind speed rises logarithmically with distance from the ground (for alpine life conditions see Cernusca 1976). Yet, the wind speed during this campaign was between 2 and $4 \mathrm{~m} \mathrm{~s}^{-1}$ at 3-m height at the nearby Furka weather station, with a sensible breeze at canopy surface apparently not sufficient to equilibrate a substantial degree of solar floral heating. Flowering unit brightness turned out not to be a significant factor, but could have a small effect as well. In the case of the nearly black orchid Nigritella, the disadvantage in terms of pollinator visibility may be compensated by a specific scent. In the black flower species J. jaquinii (Juncaceae), C. nigra, $C$. atrata (both Cyperaceae) or P. alpinum (Poaceae) pollination is predominantly by wind which suggests that these species may take thermal advantage of their black colour without disadvantages for pollination.

The results obtained here should also apply for high latitude species, which show higher floral temperatures than the ambient air on bright days, too (Mølgaard 1982; Philipp et al. 1990), and thus are likely to profit from solar radiation in the same way their alpine relatives do.

In conclusion, we provide multi-species evidence that flowering units of alpine plants profit thermally from the sun and, despite their exposure above the leaf canopy, they get in fact warmer than both ambient air and the foliage layer underneath. Higher solar radiation and larger flowering unit size favour heat accumulation. Flowering unit height above ground and brightness of flowering units contribute little to floral temperatures. High PFD values and, thus, high temperatures in flowering units can be expected to occur in a third of all daylight hours during the mid-summer flowering period in the Alps, leading to a similar floral microclimate as in plants at much lower elevation. Cushion plants make an exception in that their flowers are cooler than cushion temperature, but still much warmer than the ambient air. After abrupt shading, such as in the case of sudden cloud cover, floral temperatures return to air temperature within a few minutes, controlled by flowering unit mass. The large number of taxa surveyed gives us confidence that passive floral heating is a widespread phenomenon in alpine species. The surprisingly large size of alpine flowering units commonly explained by evolutionary selection for pollinator attraction may, thus, also be related to heat balance benefits of floral development.

Acknowledgments We thank D. Basler for technical advice and help with IR image analysis and also gratefully acknowledge comments on our manuscript by J. Wagner. The ALPFOR research station at the Furkapass provided logistic support.

\section{References}

Cernusca A (1976) Energie- und Wasserhaushalt eines alpinen Zwergstrauchbestandes während einer Föhnperiode. Arch Met Geoph Biokl Ser B 24:219-241

Fabbro T, Körner C (2004) Altitudinal differences in flower traits and reproductive allocation. Flora 199:70-81

Galen C (2006) Solar furnaces or swamp coolers: costs and benefits of water use by solar-tracking flowers of the alpine buttercup Ranunculus adoneus. Oecologia 148:195-201

Galen C, Stanton ML (2003) Sunny-side up: flower heliotropism as a source of parental environmental effects on pollen quality and performance in the snow buttercup, Ranunculus adoneus (Ranunculuaceae). Am J Bot 90:724-729

Gauslaa Y (1984) Heat resistance and energy budget in different Scandinavian plants. Holarct Ecol 7:1-78

Jones HG (2014) Plants and microclimate. A quantitative approach to environmental plant physiology, 3rd edn. University Press, Cambridge

Kevan PG (1975) Sun-tracking solar furnaces in high Arctic flowers: significance for pollination and insects. Science 189:723-726

Kjellberg B, Karlsson S, Kerstensson I (1982) Effects of heliotropic movements of flowers of Dryas octopetala L. on gynoecium temperature and seed development. Oecologia 54:10-13

Körner C (2003) Alpine plant life: functional plant ecology of high mountain ecosystems, 2nd edn. Springer, Berlin

Körner C, Diemer M (1987) In situ photosynthetic responses to light, temperature and carbon dioxide in herbaceous plants from low and high altitude. Funct Ecol 1:179-194

Kudo G (1995) Ecological significance of flower heliotropism in the spring ephemeral Adonis ramosa (Ranunculaceae). Oikos 72:14-20

Larcher W, Kainmüller C, Wagner J (2010) Survival types of high mountain plants under extreme temperatures. Flora 205:3-18

Luzar N, Gottsberger G (2001) Flower heliotropism and floral heating of five Alpine plant species and the effect on flower visiting in Ranunculus montanus in the Austrian Alps. Arct Antarct Alp Res 33:93-99 
Mølgaard P (1982) Temperature observations in high arctic plants in relation to microclimate in the vegetation of Peary Land, North Greenland. Arct Alp Res 14:105-115

Philipp M, Böcher J, Mattsson O, Woodell RJ (1990) A quantitative approach to the sexual reproductive biology and population structure in some arctic flowering plants: Dryas integrifolia, Silene acaulis and Ranunculus nivalis. Meddelser om Grønland Biosci 34:32-45

Rejskova A, Brom J, Pokorny J, Korecko J (2010) Temperature distribution in light-coloured flowers and inflorescences of early spring temperate species measured by Infrared camera. Flora 205:282-289

Rubio E, Caselles V, Badenas C (1997) Emissivity measurements of several soil and vegetation types in the $8-14 \mu \mathrm{m}$ wave band: analysis of two field methods. Remote Sens Environ 59:490-521

Scherrer D, Körner C (2010) Infra-red thermometry of alpine landscapes challenges climatic warming projections. Glob Change Biol 16:2602-2613

Sklenár P (1999) Nodding capitula in Superpáramo Asteraceae: an adaptation to unpredictable environment. Biotropica 31:394-402

Song B, Zhang ZQ, Stöcklin J, Yang Y, Yang N, Chen JG, Sun H (2012) Multifunctional bracts enhance plant fitness during flowering and seed development in Rheum nobile (Polygonaceae), a giant herb endemic to the high Himalayas. Oecologia 172:359-370

Stanton ML, Galen C (1989) Consequences of flower heliotropism for reproduction in an alpine buttercup (Ranunculus adonaeus). Oecologia 78:477-485

Stanton ML, Galen C (1993) Blue light controls solar tracking by flowers of an alpine plant. Plant Cell Environ 16:983-989

Steinacher G, Wagner J (2012) Effect of temperature on the progamic phase in high-mountain plants. Plant Biol 14:295-305
Totland $\varnothing$ (1996) Flower heliotropism in an alpine population of Ranunculus acris (Ranunculaceae): effects on flower temperature. Insect visitation and seed production. Am J Bot 83:452-458

Tsukaya H, Fujikawa K, Wu SG (2002) Thermal insulation and accumulation of heat in the downy inflorescences of Saussurea medusa (Asteraceae) at high elevation in Yunnan, China. J Plant Res 115:263-268

Van Doorn WG, van Meeteren U (2003) Flower opening and closure: a review. J Exp Bot 54:1801-1812

Wagner J, Mitterhofer E (1998) Phenology, seed development, and Reproductive success of an alpine population of Gentianella germanica in climatically varying years. Bot Acta 111:159-166

Wagner J, Ladinig U, Steinacher G, Larl I (2012) From the flower bud to the mature seed: timing and dynamics of flower and seed development in high-mountain plants. In: Lütz C (ed) Plants in alpine regions. Springer, Wein, pp 135-149

Larcher W (2012) Bioclimatic temperatures in the high Alps. In: Lütz C (ed) Plants in Alpine regions. Springer, Wein, pp 21-27

Yang Y, Körner C, Sun H (2008) The ecological significance of pubescence in Saussurea medusa, a high-elevation Himalayan "Wooly Plant". Arct Antarct Alp Res 40:250-255

Zhang S, Ai HL, Yu WB, Wang H, Li DZ (2010) Flower heliotropism of Anemone rivularis (Ranunculaceae) in the Himalayas: effects on floral temperature and reproductive fitness. Plant Ecol 209:301-312

Zhu Y, Jiang Y, Liu Q, Kang M, Spehn EM, Körner C (2009) Elevational trends of biodiversity and plant traits do not converge - $\mathrm{a}$ test in the Helan Range, NW China. Plant Ecol 205:273-283 